\title{
Do not treat the radiograph, treat the patient!
}

\author{
Röntgeni tedavi etme, hastayı tedavi et! \\ O. Şahap Atik, MD. \\ Department of Orthopedics and Traumatology, Medical Faculty of Gazi University, Ankara, Turkey
}

Osteoarthritis (OA) results from a complex system of interacting mechanical, biological, and biochemical factors. ${ }^{[1-3]}$ It is a major cause of chronic musculoskeletal pain and dysfunction.

Presence of radiographic knee osteoarthritis may influence the decision of general practitioners in their management strategies, particularly leading to increased levels of referral to secondary care. ${ }^{[4]}$ Orthopedic surgeons often refer a patient with severe radiographic knee OA for operative treatment. This is true not only regionally or nationally, but also internationally.

There are studies supporting this approach. One of these revealed that knee pain was strongly associated with joint space narrowing especially in males. ${ }^{[5]}$

However, this is a controversial issue, and there are also studies demonstrating discordance between pain and radiograph. ${ }^{[6,7]}$ In a systematic search and summary of the literature, the authors found that the proportion of those with knee pain found to have radiographic OA ranged from 15 to $76 \%$, and in those with radiographic knee OA the proportion with pain ranged from 15 to $81 \% .{ }^{[7]}$ They also concluded that considerable variation occurred with $\mathrm{X}$-ray view, pain definition, OA grading, and demographic factors.

In a recent study, the authors concluded that when the patients are not eligible for surgery, the orthopedic surgeon can confidently refer patients for nonoperative treatment even in severe radiographic knee OA or patients with high body mass index. ${ }^{[8]}$
Finally; both physicians and surgeons, all over the world, must treat the patients and not the radiographs or computed tomography scans or magnetic resonance imaging!

\section{REFERENCES}

1. Atik OŞ. The role of metabolomics in osteoarthritis for early diagnosis, monitoring prognosis and treatment. Eklem Hastalik Cerrahisi 2015;26:1.

2. Atik OŞ, Tokgöz N. Do periarticular dense bone islands cause cartilage destruction? Eklem Hastalik Cerrahisi 2013;24:39-40.

3. Baki ME, Timurkaynak A, Aydın H, Baki C. Metalon-metal dysplasia cup total hip arthroplasty for hip osteoarthritis secondary to developmental dysplasia of the hip. Eklem Hastalik Cerrahisi 2014;25:154-7.

4. Bedson J, Jordan K, Croft P. How do GPs use $x$ rays to manage chronic knee pain in the elderly? A case study. Ann Rheum Dis 2003;62:450-4.

5. Muraki S, Oka H, Akune T, Mabuchi A, En-yo Y, Yoshida $\mathrm{M}$, et al. Prevalence of radiographic knee osteoarthritis and its association with knee pain in the elderly of Japanese population-based cohorts: the ROAD study. Osteoarthritis Cartilage 2009;17:1137-43.

6. Hannan MT, Felson DT, Pincus T. Analysis of the discordance between radiographic changes and knee pain in osteoarthritis of the knee. J Rheumatol 2000;27:1513-7.

7. Bedson J, Croft PR. The discordance between clinical and radiographic knee osteoarthritis: a systematic search and summary of the literature. BMC Musculoskelet Disord 2008;9:116.

8. Skou ST, Derosche CA, Andersen MM, Rathleff MS, Simonsen O. Nonoperative treatment improves pain irrespective of radiographic severity. Acta Orthop 2015;86:599-604.

\footnotetext{
- Correspondence: O. Şahap Atik, MD. Gazi Üniversitesi Tıp Fakültesi Ortopedi ve Travmatoloji Anabilim Dalı, 06500 Beşevler, Ankara, Turkey. Tel: +90 312 - 2025528 Fax: +90 312 - 2129008 e-mail: satikmd@gmail.com
} 